\title{
Microemulsion based on Pterodon emarginatus oil and its anti-inflammatory potential
}

\author{
Henrique Pascoa ${ }^{1}$, Danielle Guimarães Almeida Diniz ${ }^{2}$, Iziara Ferreira Florentino³, \\ Elson Alves Costa ${ }^{3}$, Maria Teresa Freitas Bara ${ }^{1, *}$
}

${ }^{1}$ Laboratory of Research on Natural Products, LPPN, Faculty of Pharmacy, Federal University of Goiás, Goiânia, Goiás, Brazil, ${ }^{2}$ Laboratory of Pharmaceutical Technology, Farmatec, Faculty of Pharmacy, Federal University of Goiás, ${ }^{3}$ Laboratory of Pharmacology of Natural Products, LFPN, Institute of Biological Sciences, Federal University of Goiás, Goiania, Goiás, Brazil

\begin{abstract}
This article reports the development of a pharmaceutical product containing vegetable actives from a Brazilian medicinal plant. The possibility of forming a microemulsion using Pterodon emarginatus ("sucupira") oil was evaluated and the anti-inflammatory potential of this microemulsion was also examined. A formulation was developed using $P$. emarginatus oil, a mixture of ethoxylated Castor Oil (Ultramone ${ }^{\circledR}$ R-540/propylene glycol 2:1) (surfactant/cosurfactant) and distilled water at a ratio of 10:15:75, respectively. The microemulsion which was selected was then subjected to the preliminary stability test and analyzed in terms of average diameter of droplets, $\mathrm{pH}$, zeta potential, and polydispersity index, on the $1^{\text {st }}, 7^{\text {th }}, 15^{\text {th }}$, and $30^{\text {th }}$ days after preparation and stored at different temperatures $\left(5 \pm 2{ }^{\circ} \mathrm{C}\right.$, $25 \pm 2{ }^{\circ} \mathrm{C}$, and $40 \pm 2{ }^{\circ} \mathrm{C}$ ). The anti-inflammatory in vivo activity of both oil and formulation were evaluated, using the experimental model of croton oil-induced ear edema. The preliminary stability test showed that the microemulsion stored at 5 and $25{ }^{\circ} \mathrm{C}$ retained its original features throughout the 30 day period. The anti-inflammatory potential of both oil and formulation was shown to be statistically significant $(\mathrm{p}<0.001)$, when compared to the control group, however, the microemulsion proved to be more effective $(p<0.05)$ than the oil when applied directly to the ear.
\end{abstract}

Uniterms: Pterodon emarginatus/pharmacognosy. Pterodon emarginatus/oil/anti-inflammatory activity. Medicinal plants. Microemulsion. Phytomedicine. Pharmaceutical technology.

Descrevemos o desenvolvimento de um produto farmacêutico contendo ativo vegetal baseado em uma planta medicinal brasileira. Foi avaliada a habilidade de formação de uma microemulsão à base do óleo de Pterodon emarginatus (sucupira) e seu potential anti-inflamatório. Uma formulação foi desenvolvida utilizando o óleo de $P$. emarginatus, mistura de óleo de mamona etoxilado (Ultramona ${ }^{\circledR}$ R-540)/propilenoglicol (2:1) (tensoativo/cotensoativo) e água destilada, na proporção de 10:15:75, respectivamente. A microemulsão selecionada foi submetida ao teste preliminar de estabilidade e foi analisada quanto ao diâmetro médio das gotículas, $\mathrm{pH}$, potential zeta e índice de polidispersão, no $1^{\circ}, 7^{\circ}, 15^{\circ}$ e $30^{\circ}$ dias após o preparo e foram estocadas em diferentes temperaturas $\left(5 \pm 2{ }^{\circ} \mathrm{C}, 25 \pm 2{ }^{\circ} \mathrm{C}\right.$ e $40 \pm 2{ }^{\circ} \mathrm{C}$ ). Avaliaram-se a atividade anti-inflamatória in vivo do óleo de sucupira e da formulação, usando o modelo experimental do edema de orelha induzido pelo óleo de cróton. No teste preliminar de estabilidade observou-se que a formulação estocada a $5{ }^{\circ} \mathrm{C}$ e a $25^{\circ} \mathrm{C}$ mantiveram suas características originais durante 30 dias. O potencial anti-inflamatório de ambos, óleo de sucupira e formulação foi estatisticamente significativo ( $\mathrm{p}<0.001$ ), quando comparado ao controle, porém a microemulsão foi mais eficiente $(\mathrm{p}<0.05)$ que o óleo aplicado diretamente nas orelhas dos animais.

Unitermos: Pterodon emarginatus/pharmacognosy. Pterodon emarginatus/óleo/atividade antiinflamatória. Plantas medicinais. Microemulsão. Fitoterápico. Tecnologia farmacêutica.

\footnotetext{
*Correspondence: M. T. F. Bara. Laboratório de Pesquisa em Produtos Naturais, Faculdade de Farmácia, Universidade Federal de Goiás. Praça Universitária n 1166 - Caixa Postal 131, Setor Universitário, 74605-220 - Goiânia - GO, Brasil. Tel: +55 62 3209-6182. E-mail: mbara@ufg.br
} 


\section{INTRODUCTION}

The technological development of research on pharmaceutical forms containing herbal materials has expanded over recent decades and contributed to innovation in the pharmaceutical sector (Bassani, González, Petrovick, 2005; Calixto, 2005; Rocha et al., 2008; Araújo-Júnior et al., 2013; Beringhs et al., 2013; Couto et al., 2013; Klein et al., 2013; Quintão et al., 2013).

Emulsified systems are characterized by their capacity to deliver drugs, and depending on the size of the globule and the process used, they can be classified as macroemulsions, microemulsions or nanoemulsions (Jafari, He, Bhandari, 2007). Microemulsion systems are defined as dispersions of two immiscible liquid phases, usually oil and water, stabilized by the presence of surfactants and cosurfactants at the oil/water interfaces (Lawrence, Rees, 2000; Oliveira et al., 2004; Frange, Garcia, 2009). An average diameter of droplets in a microemulsion generally ranges from 10-100 nm (100-

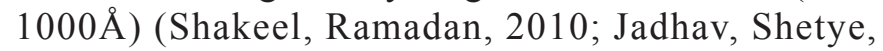
Kadam, 2010).

Microemulsion formulations can increase drug transdermal permeation, as has been demonstrated in numerous studies (Kreilgaard, Pedersen, Jaroszewski, 2000; Sintov, Sharipo, 2004; Hua et al., 2004; Sintov, Botner, 2006; Sintov, Brandys-Sitton, 2006; Heuschkel, Goebel, Neubert, 2008; Azeem et al., 2009; Neubert, 2011). Several hypotheses have been put forward for the mechanism of drug permeation enhancement. These include increased drug solubility, which fosters a high concentration gradient towards skin, small droplet size and low viscosity which facilitates permeation, increased drug thermodynamic activity in the microemulsion vehicle, and the disruption of the stratum corneum lipid order by microemulsion components (Kreilgaard, 2002; Zhao et al., 2006; Biruss, Kählig, Valenta, 2007; Gupta, Moulik, 2008; Vicentini et al., 2008; Moniruzzaman, Kamiya, Goto, 2010; Shakeel, Ramadan, 2010).

Pterodon emarginatus Vog. Fabaceae, known as "sucupira" is a tree species native to the Brazilian savanna (Lorenzi, 2002), whose fruit has shown anti-inflammatory, antiproliferactive, and antinoceptive activities (Carvalho et al., 1999; Euzébio et al., 2009; Spindola et al., 2011; Oliveira et al., 2012), based mainly on its diterpene content (Spindola et al., 2011). Although this fruit, which contains large amounts of oil, has been extensively studied both chemically and pharmacologically, there is no microemulsion product on the pharmaceutical market. Consequently, the aim of this study was to develop a microemulsion formulation containing Pterodon emarginatus oil and evaluate it for its anti-inflammatory potential.

\section{MATERIAL AND METHODS}

\section{Material}

Sorbitan monooleate $\left(\operatorname{Span}^{\circledR} 80\right)$ and PEG-54 Castor Oil (Ultramone ${ }^{\circledR}$ R540) were donated by Oxiteno. Polysorbate 80 (Tween ${ }^{\circledR} 80$ ) and propylene glycol (DEG), Ethyl alcohol (VETEC) were purchased from Atual Chemical Reagents Co. Ltda. The Pterodon emarginatus Vog. Fabaceae oil was obtained through the cold pressing of fruits collected in the town of São Domingos (Goiás Brazil) (S1342'12.9"W46²0'35.7'). The plants were identified by Dr. Jose Realino de Paula at the Universidade Federal de Goiás. A voucher specimen was deposited in the Herbarium of the Universidade Federal de Goiás (UFG), Brazil, and cataloged under number 41714.

\section{Hydrophilic-Lipophilic Balance (HLB) required by $P$. emarginatus oil}

To determine the required HLB for $P$. emarginatus oil the surfactants polysorbate 80 (Tween $80^{\circledR}$ ) with a $\mathrm{HLB}=15.0$ and sorbitan monooleate $\left(\operatorname{Span} 80^{\circledR}\right)$ with a $\mathrm{HLB}=4.3$ were used. Table I shows the composition by weight of the components. The emulsions were prepared using the classic emulsification method. After preparation, the samples were transferred to a graduated tube and left to stand at room temperature for 24 hours. The HLB required for the P. emarginatus oil corresponds to the value of the sample with the lowest creaming percentage (Pereira, 2008).

\section{Surfactant and cosurfactant system}

To obtain the $P$. emarginatus oil microemulsions certain surfactant and cosurfactant systems were evaluated to find stable formulations. According to the HLB of the oil the necessary surfactants were chosen. The compositions of the formulations tested are described in Table II. The formulations were evaluated for macroscopic parameters such as the presence of bluish reflection and translucency, and for microscopic parameters, such as Brownian motion of particles and coalescence (Pereira, 2008).

\section{Pseudo-ternary diagram}

To find the existence range of microemulsions, pseudo-ternary phase diagrams were constructed using the water titration method (Chen et al., 2004). For each 
TABLE I - Proportion of lipophilic (Tween $80^{\circledR}$ ) and hydrophilic (Span $80^{\circledR}$ ) surfactants used to obtain the required HLB for $P$. emarginatus oil

\begin{tabular}{lccccc}
\hline Test & HLB & Oil $(\mathbf{g})$ & Tween $^{8} \mathbf{\otimes}^{\circledR}(\mathbf{g})$ & Span 80 $^{\circledR}(\mathbf{g})$ & Water $(\mathbf{g})$ \\
\hline 1 & 5 & 2 & 0.13 & 1.87 & 16 \\
2 & 6 & 2 & 0.32 & 1.68 & 16 \\
3 & 7 & 2 & 0.50 & 1.50 & 16 \\
4 & 8 & 2 & 0.69 & 1.31 & 16 \\
5 & 9 & 2 & 0.88 & 1.12 & 16 \\
6 & 10 & 2 & 1.07 & 0.93 & 16 \\
7 & 11 & 2 & 1.25 & 0.75 & 16 \\
8 & 12 & 2 & 1.44 & 0.56 & 16 \\
9 & 13 & 2 & 1.63 & 0.37 & 16 \\
10 & 14 & 2 & 1.81 & 0.19 & 16 \\
11 & 15 & 2 & 2.00 & 0.00 & 16 \\
\hline
\end{tabular}

TABLE II - Determination of concentrations in percentages of the components of the formulations tested to determine the surfactant/ cosurfactant system

\begin{tabular}{lcccccc}
\hline \multirow{2}{*}{ Formulation } & \multirow{2}{*}{ Oil } & \multirow{2}{*}{ Water } & \multicolumn{2}{c}{ Surfactant } & \multicolumn{2}{c}{ Cosurfactant } \\
\cline { 3 - 7 } & & & Tween 80 $^{\circledR}$ & Ultramone R 540 $^{\circledR}$ & Ethyl alcohol $^{\text {Propylene glycol }}$ \\
\hline 1 & 6.5 & 57 & 12.5 & - & 24 & - \\
2 & 5 & 80 & 10 & - & - & 5 \\
3 & 10 & 75 & 10 & - & 5 & - \\
4 & 10 & 75 & - & 10 & - & 5 \\
5 & 10 & 75 & - & 10 & 5 & - \\
\hline
\end{tabular}

phase diagram a specific surfactant/cosurfactant weight ratio (Ultramone ${ }^{\circledR} \mathrm{R}-540 /$ propylene glycol 2:1) was used. The ratios of $P$. emarginatus oil to the mixture of surfactant/cosurfactant and water were varied every $10 \%$ covering the entire area of an equilateral triangle. After being equilibrated, the mixtures were assessed visually and classified as being either microemulsions, emulsions or gels.

\section{Microemulsion preparation}

Microemulsions were prepared by reverse-phase methods. The water phase and oil phase with surfactants were heated separately to a temperature of $75 \pm 5^{\circ} \mathrm{C}$. The aqueous phase was added into the oil phase under magnetic stirring at room temperature $\left(25^{\circ} \mathrm{C}\right)$.

\section{Characterization and stability of microemulsions}

To evaluate microemulsion stability, stress conditions including aging, temperature and centrifugation were applied. The formulations were also subjected to centrifugation at $3000 \mathrm{rpm}$ for 15 minutes at room temperature and samples were withdrawn after a particular time interval and observed for phase separation. The formulations selected were kept at three different temperatures i.e. $4^{\circ} \mathrm{C}, 25^{\circ} \mathrm{C}, 40^{\circ} \mathrm{C}$ and observed for phase separation, $\mathrm{pH}$, zeta potential and average particle size on the $1^{\text {st }}, 7^{\text {th }}, 15^{\text {th }}$, and $30^{\text {th }}$ days after preparation (ANVISA, 2004; Moghimipour, Salimi, Leis, 2012).

pH

The $\mathrm{pH}$ of the formulation was carried out using a Tecnal TEC 3MP pH meter (Tecnal, Piracicaba, São Paulo, Brazil). Analyses were performed in triplicate inserting the electrode directly into the sample without dilution (ANVISA, 2010).

\section{Zeta potential}

Zeta potential was determined by measuring the electrophoretic mobility of dispersed particles in an 
electric field (ZetaPlus, Brookhaven, New York, USA). The formulations were diluted in distilled water (1:15), homogenized until completely dispersed and then subjected to analysis, which was performed in triplicate (Silveira, 2009; Moghimipour, Salimi, Leis, 2012).

\section{Dynamic light scattering (DLS)}

The particle size of the microemulsions and the polydispersity index were determined by the laser light scattering technique (Malvern Zetasizer Nano S, Malvern, UK). The sample was diluted with distilled water (1:10) and placed in cuvettes of $1 \mathrm{~cm}^{3}$ volume at a temperature of $25^{\circ} \mathrm{C}$. The measurements were performed in triplicate (Kale, Allen Jr, 1989; Silveira, 2009; Moghimipour, Salimi, Leis, 2012).

\section{In vivo experiments}

\section{Animals}

The experiment was conducted with male Swiss mice weighing from 40 to $45 \mathrm{~g}$. They were kept under controlled temperature and light conditions (light/dark cycles of $12 \mathrm{~h}$ ) with food and water ad libitum. The antiinflammatory studies were carried out in accordance with current norms of the Brazilian College of Animal Experimentation (COBEA), and authorized by the Research Ethics Committee (number 104/08) at the Universidade Federal de Goias.

\section{Croton Oil-induced Ear Edema}

The ear edema was induced as in the procedure previously described by Tubaro et al. (1985) cited in Pinheiro et al. (2011) with modifications. Three groups with 10 mice each were used. Inflammation was induced by applying $25 \mu \mathrm{L}$ of acetone solution containing the irritant croton oil $2.5 \% \mathrm{v} / \mathrm{v}$ to the inner surface of the right ear of each animal. The left ear was used as a control and received $25 \mu \mathrm{L}$ of vehicle (acetone). Thirty minutes after applying the irritant, the mice were treated with $25 \mu \mathrm{L}$ of the microemulsion formulation without the oil (negative control), $25 \mu \mathrm{L}$ of $P$. emarginatus oil in acetone $(100 \mathrm{mg} / \mathrm{mL})$, and $25 \mu \mathrm{L}$ of the microemulsion containing the $P$. emarginatus oil.

Four hours after applying the phlogistic agent the animals were euthanized and $6 \mathrm{~mm}$ discs were taken from both ears of each animal. The difference in weight between the discs was taken as the measurement of the edema. The anti-inflammatory activity of oil and formulation was evaluated by the difference between the values obtained for the negative control and those of the other groups.

\section{Statistical Analyses}

The results were expressed as mean \pm S.D. For the group comparisons, one-way layout analysis of variance was applied. The data were analyzed statistically using variance analysis following Tukey's comparison test. $\mathrm{P}$ values less than 0.05 were considered as indicative of significance using GraphPad Prism 4 (GraphPad software, San Diego, CA, USA).

\section{RESULTS AND DISCUSSION}

\section{Hydrophilic-Lipophilic Balance (HLB) required by P. emarginatus oil}

The HLB required for the $P$. emarginatus oil was between 14 and 15 since these values presented a higher percentage of creaming as shown in Table III. The required HLB values were evaluated for the first time. The HLB parameter is an important tool for the technological development of phytopharmaceuticals and can be successfully employed in the formulation of natural products such as those based on vegetable oils (Fernandes et al., 2013)

TABLE III - Creaming profile obtained with the Tween $80^{\circledR}$ and Span $80^{\circledR}$ surfactant assessment for the HLB of $P$. emarginatus oil

\begin{tabular}{cc}
\hline HLB & \% Creaming \\
\hline 5 & - \\
6 & 3.45 \\
7 & 6.90 \\
8 & 13.79 \\
9 & 6.90 \\
10 & 13.79 \\
11 & 65.52 \\
12 & 51.72 \\
13 & 75.86 \\
14 & 79.31 \\
15 & 82.76 \\
\hline
\end{tabular}

\section{Surfactant and cosurfactant system}

The formulation with Ultramone R-540 ${ }^{\circledR} /$ Propylene glycol showed better results when the parameters were compared (Table IV). According to Mittal (1999), the possibility of forming microemulsions depends on the balance between the hydrophilic and lipophilic 
TABLE IV - Macroscopic and microscopic analysis of formulations tested to evaluate the surfactant system with increased stability

\begin{tabular}{lccccc}
\hline \multirow{2}{*}{ Formulation } & \multicolumn{5}{c}{ Macroscopic and microscopic parameters } \\
\cline { 2 - 6 } & Bluish reflection & Translucency & Brownian motion & Particle homogeneity & Coalescence \\
\hline 1 & - & + & + & + & - \\
2 & + & - & + & - & + \\
3 & - & + & + & - & + \\
4 & + & + & + & + & - \\
5 & + & & & - & + \\
\hline
\end{tabular}

properties of the surfactant, which is determined not only by its chemical structure, but also by other factors such as temperature, ionic strength and the presence of cosurfactant. Pereira (2008) used the same parameters but for olive oil, grape seed oil and a mixture of both and found that the systems showed optimal stability when using a pair of surfactants (Ultroil R300 ${ }^{\circledR}$ and $\operatorname{Span}^{\circledR} 80$ ) whose HLB was equal to 8. Kale, Allen Jr (1989), Yaghmur et al. (2002), Yotsawimonwat et al. (2006) and Moghimipour, Salimi, Leis (2012) used propylene glycol as co-surfactant in different formulations of microemulsions.

\section{Phase diagram}

Pseudoternary phase diagrams with various weight ratios of surfactant/cosurfactant, $P$. emarginatus oil and water were prepared. The region circled in Figure 1 (shown as number 22) represents the microemulsion formation regions.

Formulation $22(10 \%$ P. emarginatus oil, $20 \% \mathrm{~S} /$ $\mathrm{Co}-\mathrm{S}$, and $70 \%$ water) demonstrated greater stability for phase separation, as well as presenting the typical characteristics of the microemulsion, such as a bluish reflection, translucence, and absence of coalescence when analyzed under an optical microscope. Formulations 11, $12,13,16,17,18,23,24,29,30$, and 31 formed unstable emulsions when phase separation was complied with after centrifugation. The other formulations did not form emulsions showing gelified aspect with the separation of phases. The experimental results are described in Figure 1.

Based on these results, a new diagram was constructed around the Formulation 22 region to assess system behavior in relation to minor variations in the proportions of the components of the system. The new proportions analyzed are expressed in Table V.

The phase diagram presented in Figure 2 shows seven formulations $(37,38,39,40,41,45$ and 47) with the characteristics of a microemulsion. All formulations presented closely resembling characteristics, but Formulation 40, which had the greatest concentration of
P. emarginatus oil and a lower amount of surfactants in its composition, was selected for further study of its stability.

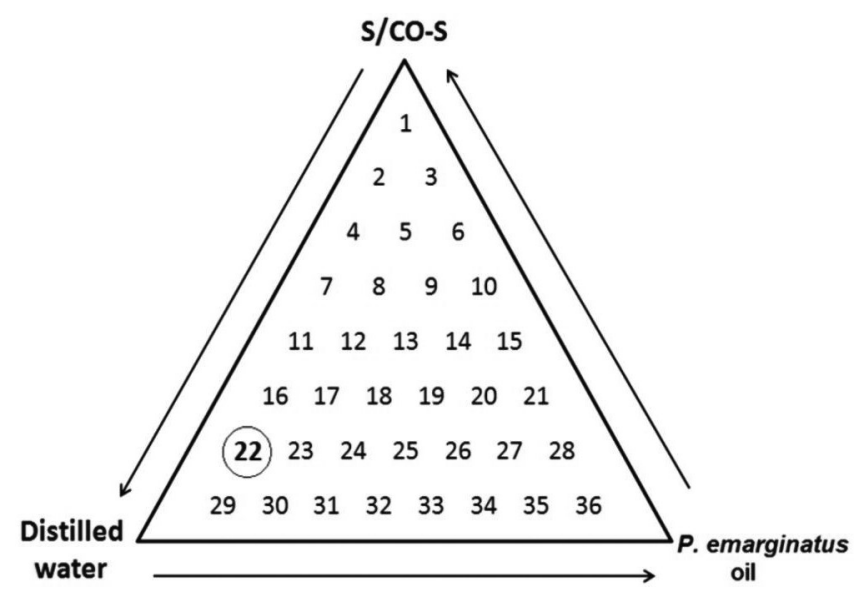

FIGURE 1 - Pseudo-ternary system for water, oil, surfactant/ cosurfactant (S/Co-S).

TABLE V - Percentage concentration (w/w) of the components of the formulation for the preparation of a new phase diagram in the microemulsion region

\begin{tabular}{lccc}
\hline Formulation & Oil & S/Co-S & Water \\
\hline 37 & 5 & 20 & 75 \\
38 & 5 & 25 & 70 \\
39 & 5 & 30 & 65 \\
40 & 10 & 15 & 75 \\
41 & 10 & 25 & 65 \\
42 & 15 & 20 & 65 \\
43 & 15 & 10 & 75 \\
44 & 15 & 15 & 70 \\
45 & 5 & 15 & 80 \\
46 & 20 & 15 & 65 \\
47 & 5 & 10 & 85 \\
48 & 10 & 10 & 80 \\
49 & 20 & 10 & 70 \\
50 & 25 & 10 & 65 \\
\hline
\end{tabular}




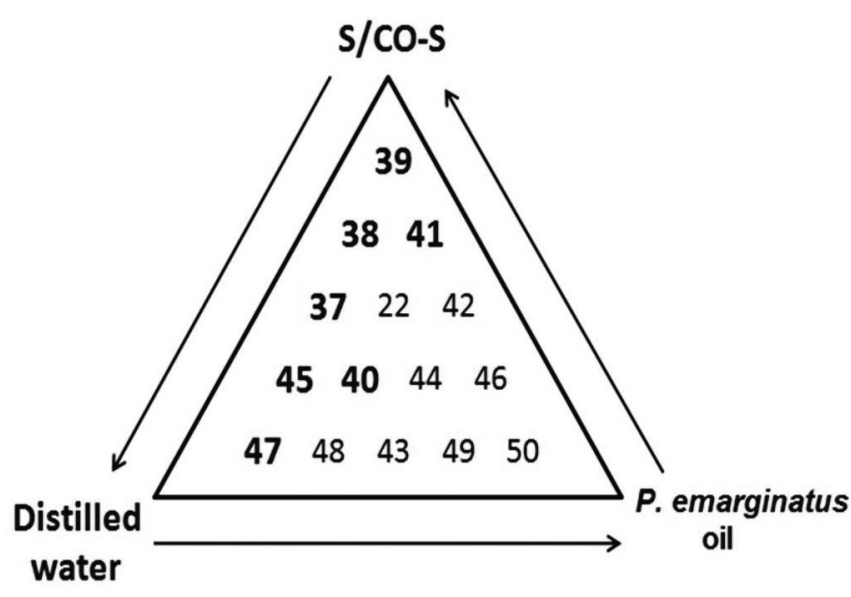

FIGURE 2 - Phase diagram in the surroundings of Formulation 22. Formulations presented in bold have the characteristics of a microemulsion while the other formulations presented only certain features of an emulsion.

The results obtained with the construction of the phase diagram are inherent to the oil and to the surfactant/ cosurfactant system used. However, Zhang, MichniakKohn (2011) using Labraso ${ }^{\circledR}$ (Caprylocaproyl macrogol 8 glycerides) and Cremophor $\mathrm{EL}^{\circledR}$ (Polyoxyl 35 Castor oil), also noted that the formulations which showed the characteristics of a microemulsion were those in which the proportion of oil was lower than the ratio of surfactant/cosurfactant. Some studies are not consistent with the optimal microemulsion concept of high water content, a balanced quantity of oil and small amount of surfactant. Such studies describe optimal microemulsion formulations with a relatively high mixture of surfactants. In all those cases, the microemulsion systems under investigation used short-chain alcohol, such as ethanol, as the co-surfactant (Yuan et al., 2006; Zhu et al., 2008). Some surfactant molecules are known to self-assemble in polar organic solvents, such as propylene glycol, glycerol, and formamide. These solvents, like water, form hydrogen bonds and have relatively high dielectric constants. Critical micelle concentrations are higher in polar nonaqueous solvents than in water. When these solvents are used as water substitutes, their resulting penetration into the surfactant interface leads to smaller or no liquid crystal phase regions. Alcohols and polyols destabilize the liquid crystalline phase and extend the isotropic region to higher surfactant concentrations (Yaghmur et al., 2002).

\section{Characterization and stability}

The microemulsion obtained retained its original features when stored at temperatures of $5{ }^{\circ} \mathrm{C}$ and $25^{\circ} \mathrm{C}$.
The formulation maintained at $40^{\circ} \mathrm{C}$ showed a significant increase in droplet size and zeta potential and a reduction in $\mathrm{pH}$ (Figures 3, 4, and 5). Such variations could be justified by the fact that the physical stability of emulsions is generally intrinsically linked to the temperature to which the product is exposed (Chorilli et al., 2009).

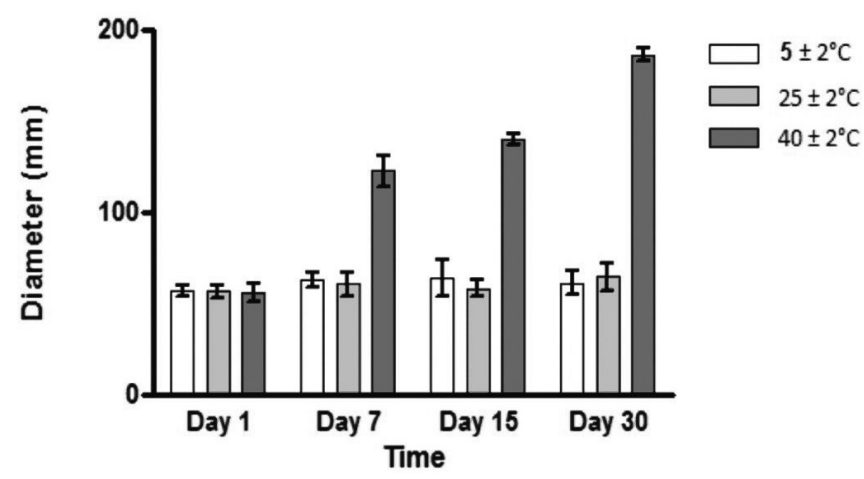

FIGURE 3 - Change in mean diameter of droplets of internal phase as a function of time. Data expressed as mean and standard deviation $(\mathrm{n}=3)$.

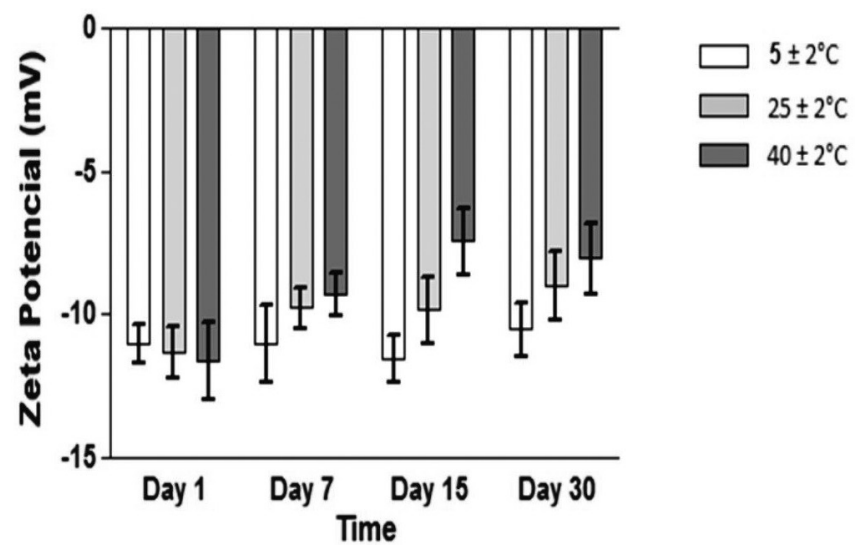

FIGURE 4 - Variation of zeta potential versus time. Data expressed as mean and standard deviation $(\mathrm{n}=3)$.

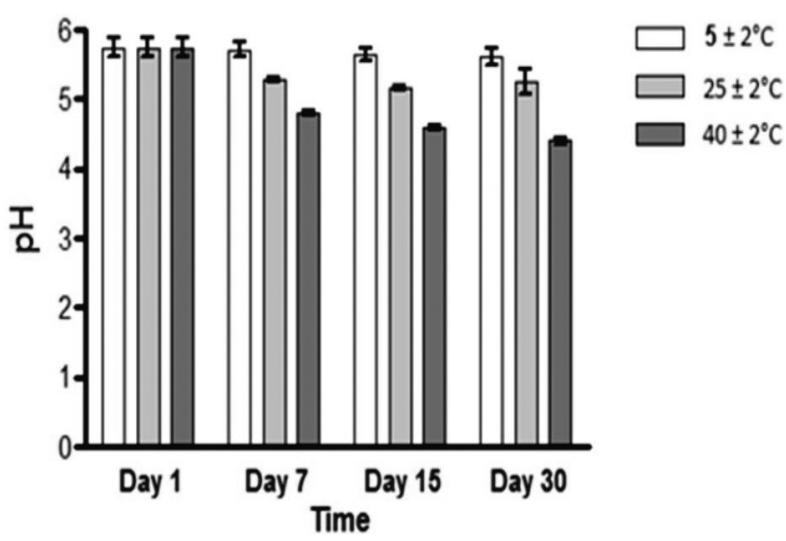

FIGURE 5 - Changes in $\mathrm{pH}$ as a function of time. Data expressed as mean and standard deviation $(\mathrm{n}=3)$. 
The decrease in $\mathrm{pH}$ led to an increase in zetapotential, which can be explained by the mechanism of load generation at the interface. The increase in negative charge density increases the concentration of hydroxyl ions in a solution that tends to favor an increase in protons and a basic $\mathrm{pH}$. On the other hand, a decrease in zeta potential, in module, as well as a more acidic $\mathrm{pH}$ can be explained by the neutralization of the negative regions as a result of the adsorption of hydrogen ions (Gallardo et al., 2005; Arias et al., 2008). The polydispersity index showed that all the microemulsions had narrow size distribution (Figure 6).

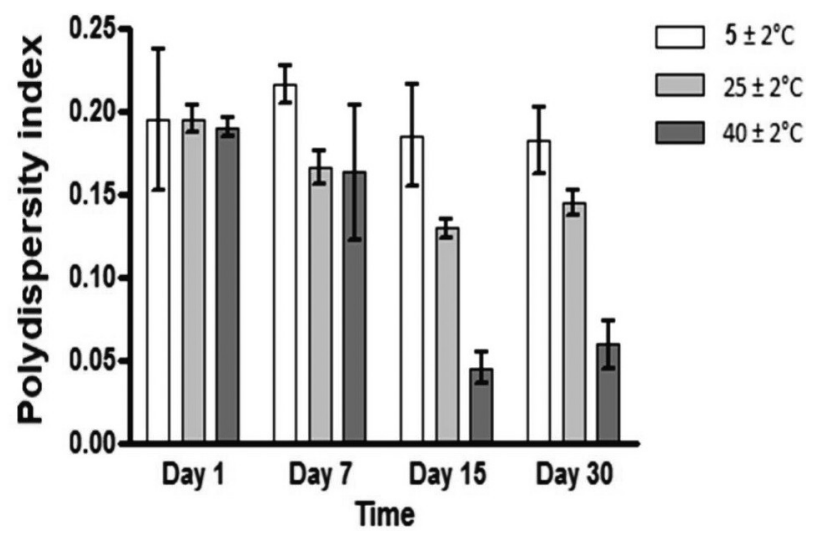

FIGURE 6 - Polydispersity index as a function of time. Data expressed as mean and standard deviation $(\mathrm{n}=3)$.

\section{Anti-inflammatory Activity}

The results obtained in the evaluation of the antiinflammatory activity of the microemulsion system (Figure 7) show that both the formulation and the oil were statistically significant when compared to the negative control $(p<0.001)$. The efficacy of the treatment was also shown

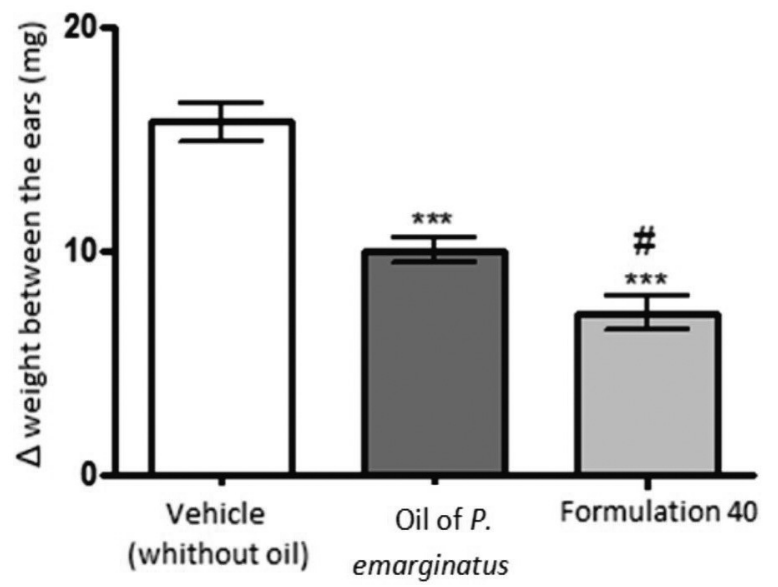

FIGURE 7 - Ear edema, in mg, induced by croton oil $(2.5 \% \mathrm{v} / \mathrm{v}$ in acetone) in groups previously treated topically. $* * * \mathrm{p}<0.001$ (ANOVA, Tukey test) for treated groups versus control group. \# $\mathrm{p}<0.05$ (ANOVA, Tukey test) between treated groups. when the use of the microemulsion with oil was compared to the application of the oil itself directly to the skin $(p<0.05)$.

After carrying out the experiment we set out to see if the anti-inflammatory potential of the oil was retained after producing the microemulsion. The results obtained for $P$. emarginatus oil are consistent with those studies which show the anti-inflammatory activity of compounds, such as $\alpha$-humulene and $\beta$-caryophyllene and vouacapanes (Spindola et al., 2011). Pinheiro et al. (2011), while employing the same experimental model, obtained a $76.63 \%$ inhibition of edema using the essential oil Peperomia serpens, which is rich in both substances. Fernandes et al. (2007) also obtained positive results for different experimental models of inflammation using $\alpha$-humulene and $\beta$-caryophyllene, administered orally, isolated from the essential oil of Cordia verbenacea.

The use of microemulsions as a carrier vehicle in the topical formulations of drugs has been shown to improve the permeability of such formulations (Dantas et al., 2010; Hathout, Woodman, Mansour, 2010; Jadhav, Shetye, Kadam, 2010; Rogerio Dora, Andrade, 2010; Tsai et al., 2010). Bolzinger et al. (2008) showed that microemulsions based on caffeine have better permeation than pharmaceutical forms, such as emulsion and gel. Problems such as low drug bioavaibility and low penetration of formulations used topically in the different skin segments have been cited (Kreilgaard, 2002).

This study presents the first description of developing a potential anti-inflammatory microemulsion using "sucupira" oil as a basis. Further studies should be undertaken to investigate the permeation of the formulation on in vitro models, evaluate its antiinflammatory mechanism of action, define pharmaceutical forms to serve as a microemulsion vehicle and perform pre-clinical and clinical trials, in the near future, in order to contribute to innovation in the phytomedicine market.

\section{CONCLUSION}

A potential anti-inflammatory phytomedicine using $P$. emarginatus oil as a basis for use in pharmaceutical forms of microemulsion was formulated and characterized. This microemulsion is comprised of $P$. emarginatus oil $(10 \%)$, a mixture of Ultramone ${ }^{\circledR} \mathrm{R}-540$ / propyleneglycol in a 2:1 ratio (15\%) and water $(75 \%)$. The average droplet diameter of the internal phase was $56.8 \pm 6.07 \mathrm{~nm}, \mathrm{pH}$ was $5.74 \pm 0.19$, zeta potential was $-11.3 \pm 1.54 \mathrm{mV}$ while the polydispersity index showed that the microemulsion had narrow size distribution. Finally, we showed the potential anti-inflammatory activity of "sucupira" oil 
and its efficacy as a vehicle in the pharmaceutical form of microemulsion.

\section{ACKNOWLEDGEMENTS}

The authors wish to thank FAPEG (Fundação de Amparo à Pesquisa de Goiás) and CAPES for their financial support.

\section{REFERENCES}

AGÊNCIA NACIONAL DE VIGILÂNCIA SANITÁRIA. ANVISA. Guia de Estabilidade de Produtos Cosméticos. 1.ed. Brasília, 2004.

AGÊNCIA NACIONAL DE VIGILÂNCIA SANITÁRIA. ANVISA. Resolução RDC n ${ }^{\circ}$, de 31 de março de 2010 - Dispõe sobre o registro de medicamentos fitoterápicos. Brasília, 2010.

ARAÚJO-JÚNIOR, C. A.; COSTA, F. S. O.; TAVEIRA S. F.; MARRETO, R. N.; VALADARES, M. C.; LIMA, E. M. Preparation of pellets containing Pothomorphe umbellata extracts by extrusion-spheronization: improvement of 4-nerolidylcatechol photostability. Braz. J. Pharmacogn., v.23, p.169-174, 2013.

ARIAS, J. L.; LOPEZ-VIOTA, M.; CLARES, B.; RUIZ, M. A. Stability of fenbendazole suspensions for veterinary use Correlation between zeta potential and sedimentation. Eur. J. Pharm. Sci., v.34, p.257-262, 2008.

AZEEM, A.; KHAN, Z. I.; AQIL, M.; AHMAD, F. J.; KHAR, R. K.; TALEGAONKAR, S. Microemulsion as a surrogate carrier for dermal drug delivery. Drug Dev. Ind. Pharm., v.35, p.525-547, 2009.

BERINGHS, A. O.; SOUZA, F. M.; CAMPOS, A. M.; FERRAZ, H. G.; SONAGLIO, D. Technological development of Cecropia glaziovi extract pellets by extrusion-spheronization. Braz. J. Pharmacogn., v.23, p.160-168, 2013.

BASSANI, V. L.; GONZÁLEZ, O. G.; PETROVICK, P. R. Desenvolvimento tecnológico de produtos fitoterápicos. Fitos, v.1, p.14-17, 2005.

BIRUSS, B.; KÄHLIG, H.; VALENTA, C. Evaluation of an eucalyptus oil containing topical drug delivery system for selected steroid hormones. Int. J. Pharm., v.328, p.142$151,2007$.
BOLZINGER, M. A.; BRIANÇON, S.; PELLETIER, J.; FESSI, H.; CHEVALIER, Y. Percutaneous release of caffeine from microemulsion, emulsion and gel dosage forms. Eur. $J$. Pharm. Biopharm., v.68, p.446-451, 2008.

CALIXTO, J. B. Twenty-five years of research on medicinal plants in Latin America: a personal view. J. Ethnopharmacol., v.100, p.131-134, 2005.

CARVALHO, J .C. T.; SERTIÉ, J. A. A.; BARBOSA, M. V. J.; PATRICIO, K. C. M.; CAPUTO, L. R. G.; SARTI, S. J.; FERREIRA, L. P.; BASTOS, J. K. Antiinflamatory activity of the crude extract from the fruits of Pterodon emarginatus Vog. J. Ethnopharmacol., v.64, p.127-133, 1999.

CHEN, H.; CHANG, X.; WENG, T.; ZHAO, X.; GAO, Z.; YANG, Y.; XU, H.; YANG, X. A study of microemulsion systems for transdermal delivery of triptolide. J. Control. Release, v.98, p.427-436, 2004.

CHORILLI, M.; PRESTES, P. S.; RIGON, R. B.; LEONARDI, G. R.; CHIAVACCI, L. A.; SCARPA, M. V. Desenvolvimento de sistemas líquido-cristalinos empregando silicone fluido de co-polímero glicol e poliéter funcional siloxano. Quim. Nova, v.32, p.1036-1040, 2009.

COUTO, A. G.; KUNZLER, M. L.; SPANIOL, B.; MAGALHÃES, P. M.; ORTEGA, G. G.; PETROVICK, P. R. Chemical and technological evaluation of the Phyllanthus niruri aerial parts as a function of cultivation and harvesting conditions, Braz. J. Pharmacogn., v.23, p.36-43, 2013.

DANTAS, T. N. C.; SILVA, H. S. R. C.; MARCUCCI, M. C.; NETO, A. A. D.; MACIEL, M. A. M. Development of a new propolis microemulsion system for topical applications. Braz. J. Pharmacogn., v.20, p.368-375, 2010.

EUZÉBIO, F.P.G.; SANTOS, F.J.L.; PILÓ-VELOSO, D.; RUIZ, A. L. T. G.; CARVALHO, J. E.; FERREIRA-ALVES, D. L.; FÁTIMA, A. Effect of 6a,7b-dihydroxyvouacapan-17boic acid and its lactone derivatives on the growth of human cancer cells. Bioorg. Chem., v.37, p.96-100, 2009.

FERNANDES, E. S.; PASSOS, G. F.; MEDEIROS, R.; CUNHA, F. M.; FERREIRA, J.; CAMPOS, M. M.; PIANOWSK, L. F.; CALIXTO, J. B. Anti-inflammatory effects of compounds alpha-humulene and (-)-transcaryophyllene isolated from the essential oil of Cordia verbenacea. Eur. J. Pharmacol., v.569, p.228-236, 2007. 
FERNANDES, C. P.; MASCARENHAS, M. P.; ZIBETTI, F. M.; LIMA, B. G.; OLIVEIRA, R.P.R.F.; ROCHA L.; FALCÃO, D. Q. HLB value, an important parameter for the development of essential oil phytopharmaceuticals. Braz. J. Pharmacogn., v.23, p.108-114, 2013.

FRANGE, R. C. C.; GARCIA, M. T. J. Desenvolvimento de emulsões óleo de oliva/água: avaliação da estabilidade física. Rev. Cienc. Farm. Basica. Apl., v.30, p.263-271, 2009.

GALLARDO, V.; MORALES, M. E.; RUIZ, M.A.; DELGADO, A. V. An experimental investigation of the stability of ethylcellulose latex: correlation between zeta potential and sedimentation. Eur. J. Pharm. Sci., v.26, p.170-175, 2005.

GUPTA, S.; MOULIK, S. P. Biocompatible microemulsions and their prospective uses in drug delivery. J. Pharm. Sci., v.97, p.22-45, 2008

HATHOUT, R.M.; WOODMAN, T.J.; MANSOUR, S. Microemulsion formulations for the transdermal delivery of testosterone. Eur. J. Pharm. Sci., v.40, p.188-196, 2010.

HEUSCHKEL, S.; GOEBEL, A.; NEUBERT, R. H. H. Microemulsions-modern colloidal carrier for dermal and transdermal drug delivery. J. Pharm. Sci., v.97, p.603-631, 2008.

HUA, L.; WEISAN, P.; JIAYU, L.; YING, Z. Preparation, evaluation and NMR characterization of vinpocetine microemulsion for transdermal delivery. Drug Dev. Ind. Pharm., v.30, p.657-666, 2004.

JADHAV, K. R.; SHETYE, S. L.; KADAM, V. J. Design and Evaluation of Microemulsion Based Drug Delivery System. Int. J. Adv. Pharm. Sci., v.1, p.156-166, 2010.

JAFARI, S. M.; HE, Y.; BHANDARI, B. Encapsulation of Nanoparticles of d-Limonene by Spray Drying: Role of Emulsifiers and Emulsifying techniques. Dry Technol., v.25, p.1079-1089, 2007.

KALE, N. J; ALLEN JR, L. V. Studies on microemulsions using Brij 96 as surfactant and glycerin, ethylene glycol and propylene glycol as cosurfactants. Int. J. Pharm., v.57, p.87-93, 1989.

KLEIN, T.; LONGHINI, R.; BRUSCHI, M. L.; PALAZZO DE MELLO, J. C. Development of tablets containing semipurified extract of guaraná (Paullinia cupana). Braz. J. Pharmacogn., v.23, p.186-193, 2013.
KREILGAARD, M. Influence of microemulsions on cutaneous drug delivery. Adv. Drug Delivery Rev., v.54, p.s77-s98, 2002.

KREILGAARD, M.; PEDERSEN, E. J.; JAROSZEWSKI, J. W. NMR characterization and transdermal drug delivery potential of microemulsion systems. J. Control. Release, v.69, p.421-433, 2000

LAWRENCE, M. J.; REES, G. D. Microemulsion-based media as novel drug delivery systems. Adv. Drug Deliver. Rev., v.45, p.89-121, 2000.

LORENZI, H. Árvores brasileiras: manual de identificação e cultivo de plantas arbóreas nativas do Brasil. São Paulo: Instituto Plantarum,2002. 242p.

MOGHIMIPOUR, E.; SALIMI, A.; LEIS, F. Preparation and evaluation of Tretinoin microemulsion based on PseudoTernary Phase Diagram. Adv. Pharm. Bulletin., v.2, p.141$147,2012$.

MONIRUZZAMAN, M.; KAMIYA, N.; GOTO, M. Ionic liquid based microemulsion with pharmaceutically accepted components: Formulation and potential applications. $J$. Colloid Interface Sci., v.352, p.136-142, 2010.

MITTAL, L. K. Handbook of microemulsion science and technology. New York: Promod Kumar, 1999.

NEUBERT, R. H. H. Potential of new nacocarriers for dermal and transdermal drug delivery. Eur. J. Pharm. Biopharm., v.77, p.1-2, 2011.

OLIVEIRA, A. G.; SCARPA, M. V.; CORREA, M. A.; CERA, L. F. R.; FORMARIZ, T. P. Microemulsões: estrutura e aplicações como sistema de liberação de fármacos. Quím. Nova, v.27, p.131-138, 2004.

OLIVEIRA, P. C.; CONCEIÇÃO, E. C.; OLIVEIRA, P. A.; NASCIMENTO, M. V.; COSTA, E. A.; PAULA, J. R.; BARA, M. T. F. Obtaining a dry extract of Pterodon emarginatus (Fabaceae) Fruits by Spray-Drying. J. Pharm. Res., v.5, p.641-645, 2012.

PEREIRA, G. G. Obtenção de nanoemulsões O/A à base de óleo de semente de uva e oliva aditivadas de metoxicinamato de octila e estudo do potencial antioxidante e fotoprotetor das emulsões. Dissertação (Mestrado) - Faculdade de Ciências Farmacêuticas de Ribeirão Preto, Universidade de São Paulo. Ribeirão Preto, 2008. 
PINHEIRO, B. G.; SILVA, A. S. B.; SOUZA, G. E. P.; FIGUEIREDO, J. G.; CUNHA, F. Q.; LAHLOU, S.; SILVA, J. K. R.; MAIA, J. G. S.; SOUSA, P .J. C. Chemical composition, antinociceptive and anti-inflammatory effects in rodents of the essential oil of Peperomia serpens (Sw.) Loud. J. Ethnopharmacol., v.138, p.479-486, 2011.

QUINTÃO, F. J. O.; TAVARES, R. S. N.; VIEIRA-FILHO, S. A.; SOUZA, G. H. B.; SANTOS, O. D. H. Hydroalcoholic extracts of Vellozia squamata: study of its nanoemulsions for pharmaceuticalor cosmetic applications. Braz. J. Pharmacogn., v.23, p.101-107, 2013.

ROCHA, L.; LUCIO, E. M. A.; FRANÇA, H. S.; SHARAPIN, N. Mikania glomerata Spreng: Desenvolvimento de um produto fitoterápico. Braz. J. Farmacogn., v.18, p.744-747, 2008.

ROGERIO, A. P.; DORA, C. L.; ANDRADE, E. L. Antiinflammatory effect of quercetin-loaded microemulsion in the airways allergic inflammatory model in mice. Pharmacol. Res., v.61, p.288-297, 2010.

SILVEIRA, W. L. L. Desenvolvimento e caracterização de um sistema microemulsionado contendo anfotericina B para uso oftalmológico. Universidade Federal do Rio Grande do Norte. Dissertação. 2009.

TSAI, Y. H.; LEE, K. F.; HUANG, Y. B.; HUANG, C. T.; WU, P. C. In vitro permeation and in vivo whitening effect of topical hesperetin microemulsion delivery system. Int. J. Pharm., v.388, p.257-262, 2010.

SHAKEEL, F.; RAMADAN, W. Transdermal delivery of anticancer drug caffeine from water-in-oil nanoemulsions. Colloid Surface B., v.75, p.356-362, 2010.

SPINDOLA, H. L.; SERVAT, L.; RODRIGUES, R. A. F.; SOUSA, I. M. O.; CARVALHO, J. E.; FOGLIO, M. A. Geranylgeraniol and $6 \alpha, 7 \beta$-dihydroxyvouacapan-17 $\beta$-oate methyl ester isolated from Pterodon pubescens Benth.: Further investigation on the antinociceptive mechanisms of action. Eur. J. Pharmacol., v.656, p.45-51, 2011.

SINTOV, A. C.; BOTNER, S. Transdermal drug delivery using microemulsion and aqueous systems: influence of skin storage conditions on the in vitro permeability of diclofenac from aqueous vehicle systems. Int. J. Pharm., v.311, p.5562, 2006.
SINTOV, A. C.; BRANDYS-SITTON, R. Facilitated skin penetration of lidocaine: combination of a short-term iontophoresis and microemulsion formulation. Int. J. Pharm., v.316, p.58-67, 2006.

SINTOV, A. C.; SHAPIRO, L. New microemulsion vehicle facilitates percutaneous penetration in vitro and cutaneous drug bioavailability in vivo. J. Control. Release, v.95, p.173-183, 2004.

VICENTINI, F. T. M .C.; SIMI, T. R. M.; DEL CIAMPO, J. O.; WOLGA, N. O.; PITOL, D. L.; IYOMASA, M. M.; BENTLEY, M. V. L B.; FONSECA, M. J. V. Quercetin in w/o microemulsion: In vitro and in vivo skin penetration and efficacy against UVB-induced skin damages evaluated in vivo. Eur. J. Pharm. Biopharm., v.69, p.948-957, 2008.

YOTSAWIMONWAT, S.; OKONOKI, S.; KRAUEL, K.; SIRITHUNYALUG, J.; SIRITHUNYALUG, B.; RADES, T. Characterisation of microemulsions containing orange oil with water and propylene glycol as hydrophilic components. Pharmazie, v.61, p.920-926, 2006.

YUAN, Y., LI, S., MO, F., ZHONG, D. Investigation of microemulsion system for transdermal delivery of meloxicam. Int. J. Pharm., v.321, p.117-123, 2006.

YAGHMUR, A.; ASERIN, A.; GARTI, N. Phase behavior of microemulsions based on food-grade nonionic surfactants: effect of polyols and short-chain alcohols. Colloid Surface $A$, v.209, p.71-81, 2002.

ZHAO, X.; LIU, J. P.; ZHANG, X.; LI, Y. Enhancement of transdermal delivery of theophylline using microemulsion vehicle. Int. J. Pharm., v.327, p.58-64, 2006.

ZHANG, J.; MICHNIAK-KOHN, B. Investigation of microemulsion microstructures and their relationship to transdermal permeation of model drugs: ketoprofen, lidocaine, and caffeine. Int. J. Pharm., v.421, p.34-44, 2011.

ZHU, W., YU, A., WANG, W., DONG, R., WU, J., ZHAI, G. Formulation design of microemulsion for dermal delivery of penciclovir. Int. J. Pharm., v.360, p.184-190, 2008.

Received for publication on $03^{\text {rd }}$ September, 2013 Accepted for publication on $02^{\text {nd }}$ November 2014 